\title{
Use of concrete block waste as aggregate in structural concrete block
}

\author{
Utilização de resíduos de blocos de concreto como agregado em bloco de \\ concreto estrutural
}

\author{
Ana Paula Favretto Bussolaro' \\ Elaise Gabriel" \\ Gabriela Meller'II \\ Ursula Maira Maciel Rigon ${ }^{\text {IV }}$ \\ Marlon Leãov
}

\begin{abstract}
Civil construction generates a large amount of waste and consequently faces problems in the final destination of these materials. Among the most common materials, we can highlight concrete as the second largest waste generator, therefore being a problem for society. In this context, this research analyzed the use of residues of concrete blocks as aggregate in the structural block of the building. For this, structural concrete blocks with different recycled waste contents were molded and later submitted to tests of resistance to compression, water absorption and dimensional analysis. The results showed that the addition of recycled residues caused an increase in water absorption and a reduction in compressive strength as the conventional aggregate was replaced by the recycled aggregate. It was concluded that concrete residues can be applied as an aggregate of structural concrete block provided that it respects certain limits of residue content. The application of the technique can consume the entire residue coming from the manufacture of structural concrete blocks.
\end{abstract}

Keywords: Recycling, reuse, residue grinder, compressive strength.

\section{Resumo}

A construção civil gera uma grande quantidade de resíduos e consequentemente enfrenta problemas na destinação final destes materiais. Dentre os materiais mais comuns, podemos destacar o concreto como o segundo maior gerador de resíduos, sendo assim um problema para a sociedade. Neste contexto, esta

\footnotetext{
I Engenheira Civil, Universidade do Estado de Mato Grosso - UNEMAT, Sinop, MT, Brasil -

" Mestre em Engenharia Civil, Universidade Federal de Santa Maria, Santa Maria, RS, Brasil -

"'Doutoranda em Engenharia Civil, Universidade Federal de Santa Maria, Santa Maria, RS, Brasil -

IV Engenheira Civil, Universidade do Estado de Mato Grosso - UNEMAT, Sinop, MT, Brasil -

$\checkmark$ Professor, Departamento de Engenharia Civil, Universidade do Estado de Mato Grosso - UNEMAT, Sinop, MT, Brasil
} 
estrutural. Para isto foram moldados blocos de concreto estrutural com diferentes teores de resíduos reciclados e posteriormente submetidos a ensaios de resistência a compressão, absorção de água e análise dimensional. Os resultados mostraram que o acréscimo de resíduos reciclados provocou um aumento da absorção de água e uma redução da resistência a compressão, à medida que é substituído o agregado convencional pelo agregado reciclado. Concluiu-se que resíduos de concreto podem ser aplicados como agregado em bloco de concreto estrutural desde que respeitando certos limites de teor de resíduo. A aplicação da técnica pode consumir todo o resíduo proveniente da fabricação de blocos de concreto estrutural.

Palavras-chave: reciclagem, reuso, moedor de resíduo, resistência à compressão.

\section{Introduction}


The construction industry is one of the main sources of environmental impacts. The heating of the construction market, therefore, generates a large amount of waste. In order to reduce environmental impacts, there is a need to minimize these residues or to adopt methods to reuse them, thus enabling the new generations to enjoy the natural resources that still exist.

In Brazil, the use of waste from civil construction has been increasing in recent times. Being used in the base and sub-base layers of highways and in the manufacture of nonstructural concrete. However, some researchers point out that it is possible to use recycled aggregates in concrete with structural function but there is no regulatory standard for the case (DALPINO, 2008).

Concrete is one of the most used materials by humankind, and consequently it is the second material that most generates debris in Brazil, with 21.1\% being behind the mortar that owns $37.4 \%$ of the total of the residues coming from the civil construction (ZORDAN; PAULON, 1998).

Reuse of concrete wastes can decrease the amount of wasted material and avoid degradation of environments where waste is discarded. Therefore, obtaining these alternatives is extremely important for the use of these wastes. An alternative is to replace conventional aggregates with those obtained through recycling, and add, for example, to concrete blocks.

The concrete block is the main material used in structural masonry. According to Camacho (2006), the use of structural masonry has been increasing every day, proving to be an excellent constructive solution, because it provides greater speed and a lower cost compared to masonry of ceramic bricks, reaching a reduction of $30 \%$ of the total value of the construction work.

In the county of Sinop-MT, city used as field of study, the recycling of debris is not a very widespread technique and most of the waste is sent to the dump of the city. The concrete and block industries that serve the city and region generate a large amount of waste, however, in most of these industries the wastes are still not reused and are only stored. 
Thereby, the purpose of this work was to use the residues of concrete blocks, from defective blocks in a company, in the replacement of some of the aggregates commonly used in the manufacture of structural concrete blocks.

For this, a suitable concrete mix was used for the manufacture of blocks, class B according to NBR 6136 (ABNT, 2006), replacing in parts the common fine aggregates for those obtained from the recycling of concrete wastes. Afterwards, the compressive strength and the water absorption of the blocks were verified.

With this, it was possible to compare the compressive strength and water absorption resistances of the molded blocks with recycled aggregate and the molded blocks with conventional aggregates.

\subsection{Structural concrete blocks}

The components that form the structural masonry are the following: Structural concrete blocks, mortar, grout (high flow micro concrete) and reinforcing steel if necessary. Concrete blocks for structural masonry must meet all the requirements of Brazilian Standard - NBR 6136: simple concrete hollow blocks for masonry - Requirements (ABNT, 2006). The blocks consist of a mixture of Portland cement, aggregates, water and additives in some cases. Together with the mortar, the blocks resist the structural strains (BERENGUER, 2010).

According to NBR 6136 (ABNT, 2006), the blocks must have sharp edges and must not contain cracks, fractures or other imperfections that may affect their laying, strength and durability. According to the same NBR, the blocks are classified according to their dimensions by families. They can be integral blocks, $L$ and $T$ mooring blocks, compensating blocks $A$ and $B$ (for modulation adjustment) and channel type blocks.

Class A - With structural function, for use in masonry elements above or below ground level. Characteristic resistance greater than $6 \mathrm{MPa}$;

Class B - With structural function, for use in masonry elements above ground level. Characteristic resistance greater than $4 \mathrm{MPa}$;

Class C - With structural function, for use in masonry elements below ground level. Characteristic resistance greater than $3 \mathrm{MPa}$; 
Class D - No structural function, for use on elements above ground level. Characteristic resistance greater than $2 \mathrm{MPa}$.

The blocks with recycled waste molded in this research aimed to Class B.

\subsubsection{Manufacturing process of structural concrete blocks}

According to NBR 6136 (ABNT, 2006) the blocks must have a homogeneous appearance, be compact and free of imperfections, that is why the fabrication and the healing process are of great importance.

\subsubsection{Storage of aggregates}

The aggregates represent about $75 \%$ to $85 \%$ of the total volume of the mixture that makes up the mass of the blocks. Good storage ensures non-contamination of the aggregates and enables a consistent dosage throughout the process (PIRES SOBRINHO et al., 2008).

According to NBR 12655: Concrete - preparation, control and receipt (ABNT, 1996), the materials that make up the concrete must be stored at the factory or work site, separated from receiving the loads to the mixture.

\subsubsection{Dosage}

The composition of each concrete must be defined, in a rational or experimental dosage, well in advance of concreting. The dosage study shall be made with the same materials and conditions as those of the work site or manufacture (ABNT, 1996). The measurement of materials can be made by the weight or volume of each material (PIRES SOBRINHO et al., 2008).

The water should have its dosage corrected, since the variations of the humidity contents in the aggregates are inevitable, and fundamental for the molding of the blocks (MEDEIROS, 1993). Often in industries, water is added depending on the experience of employees, causing dosing errors.

According to Oliveira and Araújo (2013), the determination of the amount of moisture in the aggregates can be done by the greenhouse method where the aggregates are 
weighed wet and dry after oven drying, and thus the total moisture is found according to equation 1:

$h=\frac{M_{h}-M_{s}}{M_{s}} * 100$

Where:

$\mathrm{Mh}=$ Wet sample mass $(\mathrm{g})$;

Ms = Dry sample mass $(\mathrm{g})$;

$\mathrm{h}=$ Humidity of the aggregates (\%).

\subsubsection{Mixture}

According to Pires Sobrinho et al. (2008), the mixing equipment is very important because it allows the homogenization of the materials. There are three types of mixers: vertical axis plenum; horizontal axis force, and tilting.

\subsubsection{Forming equipment}

The equipment used for blocks manufacture is called vibro-presses. According to Sousa (2001), the machine received this name after having the vibration and pressing mechanism employed simultaneously during the manufacturing process. It is responsible for filling, densification and controlling the height of the block.

There are three types of vibro-presses, the pneumatic ones, which it depends on the capacity of the compressor, showing efficiency in the conformation. Hydraulic vibropresses that are driven by pump pressure and ensure a good conformation of the blocks. Lastly, the mechanics, which it is very limited and do not guarantee a good quality, because the blocks produced have high porosity and low resistance.

According to Medeiros (1993), the basic sequence for the operation of the machines can be summarized in the following steps:

Fill the feeder drawer with molding material; 
Fill the metal mold where the blocks will be molded. The vibration of the mold accompanies this step as shown in Figure 1.

Return of the drawer to its initial position and block compression through the extractors. This step also accompanies the vibration, which it only ends when the desired height of the blocks are reached;

Decompression of the blocks after the end of the vibration, the blocks leave the forms upon pallets.

The pallet with the newly formed blocks moves forward, through a brush that removes excess material from the top, and thus begins a new cycle.

Figure 1 - Mold filling with concrete

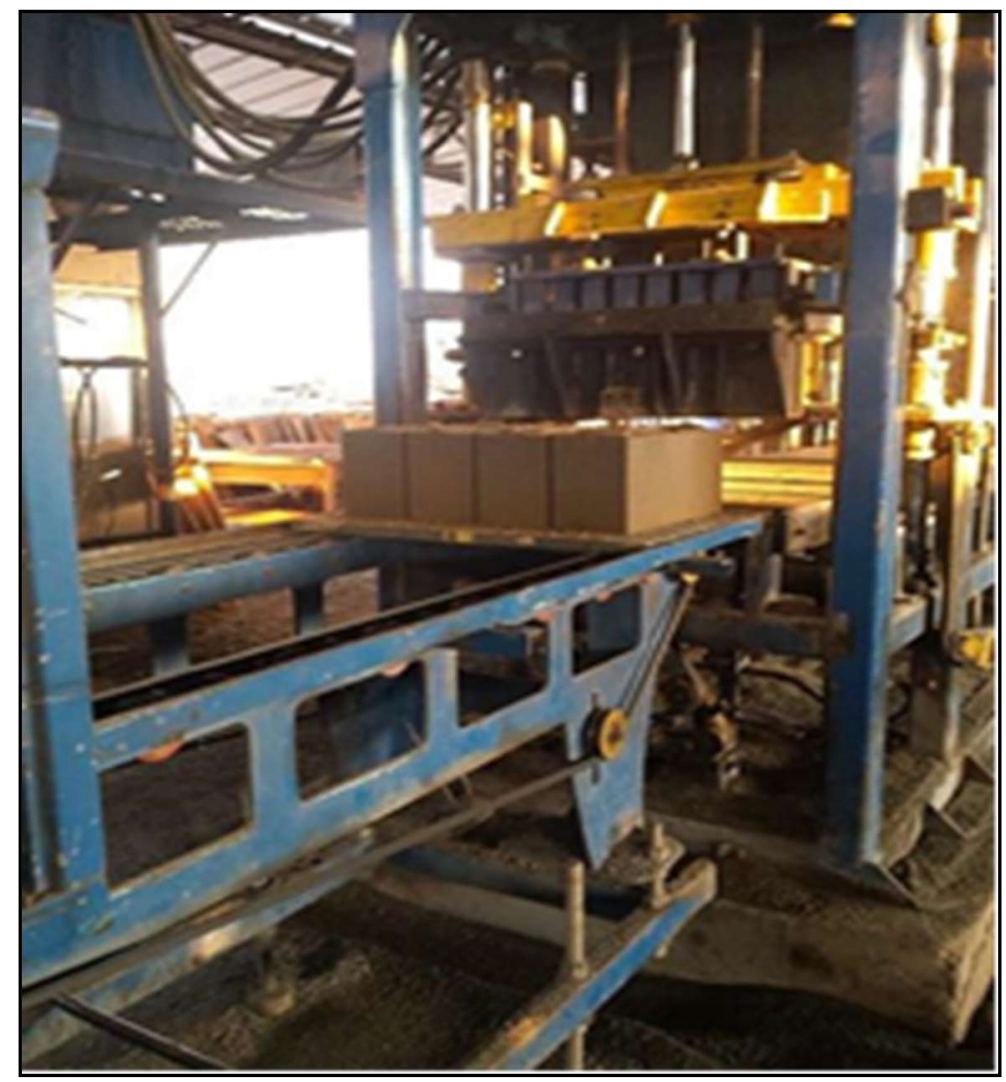

Source: own collection, 2013.

According to Metha and Monteiro (2006), the term concrete curing involves the combination of conditions that promote cement hydration, i.e., time, temperature and humidity conditions immediately after the addition of the materials. In all chemical reactions the temperature has an accelerating effect on hydration reactions. At normal 
temperature the constituents of the Portland cement begin to hydrate as soon as the water is added. Figure 2 represents the curing time of the blocks.

Figure 2 - Concrete blocks cure.

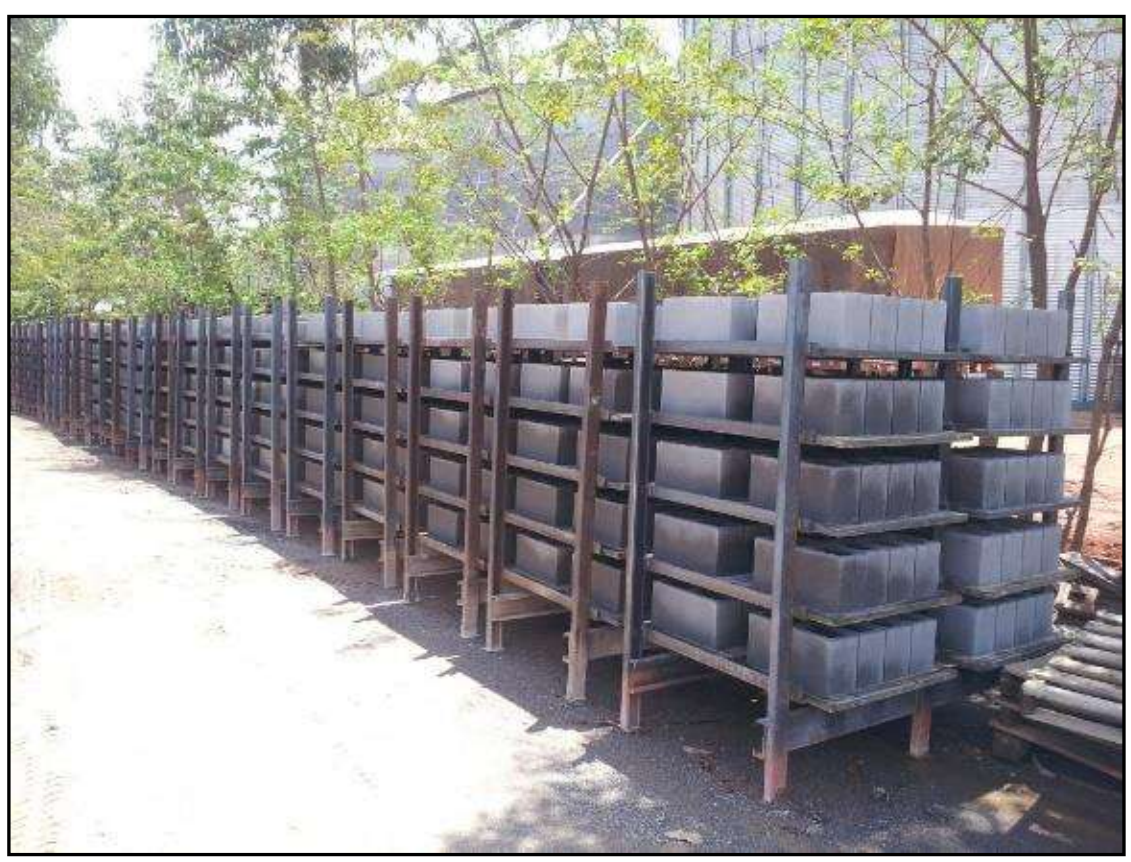

Source: own collection, 2013.

According to Sousa (2001), curing is another important process in the production of concrete blocks. After the molding, the blocks are placed in racks for 7 days, as shown in Figure 2. Later, they are stacked in pallets, where they remain for 14 to 28 days to obtain resistance. Natural healing is often employed where climatic conditions favor rapid hardening of the concrete. In this type of cure, it is recommended that the blocks are protected from the wind and constantly moist, for at least the first seven days (TANGO, 1984, apud SOUSA, 2001).

\subsubsection{Physical properties of structural concrete blocks}

The cast concrete blocks must undergo tests to meet the requirements of standard NBR 6136: 2006 (ABNT, 2006). One of the tests is the water absorption, which it measures the percentage of water absorbed by the block; this should not be greater than $10 \%$. 
The standard still establishes the limits of linear retraction and the values of resistance to compression, Table 1. The compressive strength test is used to verify the loads that the blocks can withstand if subjected to external forces. For this research, the blocks were considered to be Class $\mathrm{B}$, that is, $4 \mathrm{MPa}$.

Table 1 - Requirements for compression, absorption and retraction resistance.

\begin{tabular}{c|c|c|c}
\hline Class & $\begin{array}{c}\text { Fbk characteristic } \\
\text { resistance (MPa) }\end{array}$ & $\begin{array}{c}\text { Average } \\
\text { absorption (\%) }\end{array}$ & Retraction (\%) \\
\hline $\mathrm{A}$ & $\geq 6.0$ & & \\
\hline $\mathrm{B}$ & $\geq 4.0$ & $\leq 10.0$ & $\leq 0.065$ \\
\hline $\mathrm{C}$ & $\geq 3.0$ & & \\
\hline $\mathrm{D}$ & $\geq 2.0$ & & \\
\hline
\end{tabular}

\section{Materials and Methods}

For the accomplishment of this research, residues of concrete blocks were collected in an Industry located in the city of Sinop-MT. These collected residues come from blocks that the quality control of the Industry did not accept them, because it contains some type of defect. According to the Industry in question, these rejected blocks amount to $0.1 \%$ of production.

The second step was to grind these residues in granulometry suitable for use. The residues were broken into smaller pieces, as shown in Figure 3, and then they were ground. For this, it was used a grinding machine, which it was made available by a construction company in the city.

(Continue...)

Figure 3 - Waste blocks. 


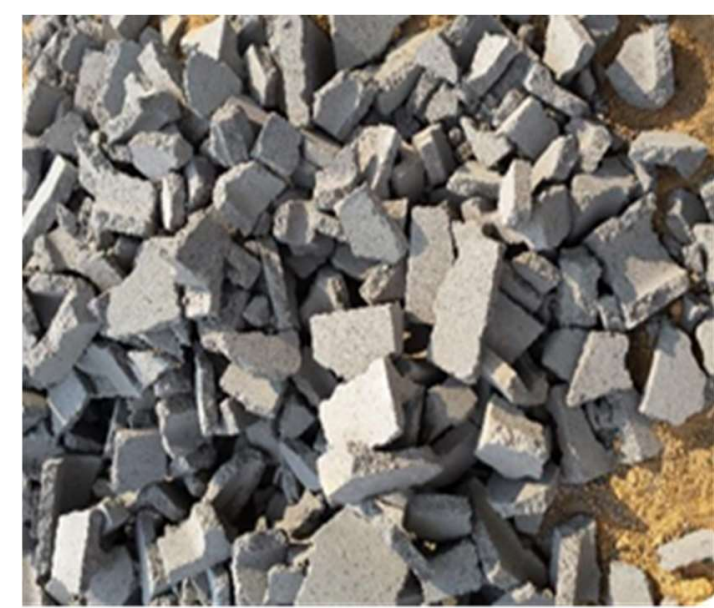

Source: own collection, 2014.

The next step was to sift the crushed residue, as the machine crushed the material in various granulometries. For the process, a sieve of $4.75 \mathrm{~mm}$ was used, where the entire large aggregate was retained. To characterize the waste used, the granulometric curve of the material was made, using the sieves standardized by ABNT. In Figure 4, the graphs show the comparison of the grain size curve of each material, the crushed residue, the sand and the stone powder.

Figure 4 - Granulometric curves of the aggregates.

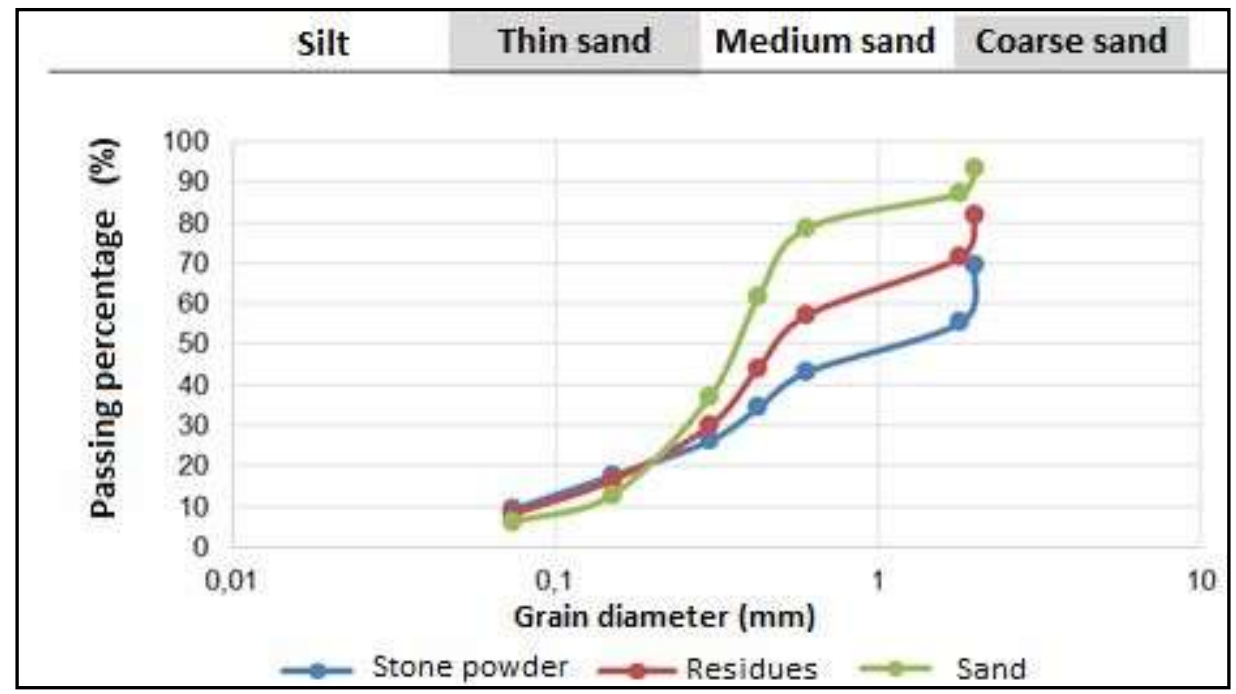

As the graph shows, the grain size curve of the crushed residue and the stone powder are similar, and so, the stone powder can actually be replaced by the residue.

Subsequently, the new aggregate was packed in plastic bags and transported to the block 
industry. The other materials used in the construction of the blocks, such as cement (CP II $Z$ ), additive (superplastizing), stone powder, hail and medium sand; they were used from the industry itself.

In this research three traces of concrete were tested, replacing the stone powder with the recycled fine aggregate. The standard trait used was 1:15, that is, $1 \mathrm{~kg}$ of cement for 15 $\mathrm{kg}$ of aggregates, the aggregates were: medium sand, stone powder and hail (1: 7: 4: 4). It can be said that the cement corresponds to $7 \%$ of the trace, while the sand corresponds to $43 \%$, and the stone powder and hail correspond to $25 \%$ each.

The chosen trait is the same used in the industry, where the blocks were molded, with this it is possible to make a comparison with the structural blocks usually manufactured. The blocks were manufactured by replacing the stone powder with recycled debris, varying its percentage, starting with the $10 \%$ content, and then increasing to $20 \%$ and $30 \%$ residue.

For the correction of the aggregates humidity, samples of all aggregates were tested. Moisture of the stone powder presented: $0.22 \%$; hailstones: $0.18 \%$; residue: $0.37 \%$ and sand: $2.43 \%$ moisture. Therefore the water content of the trace was corrected from these humidities.

According to Moraes (2012), Equation 2 can be used to correct water according to the humidity of the aggregate:

$$
A c=A i-\left(\frac{U}{100} * M_{a}\right)
$$

Ac $=$ Corrected water;

$A i=$ Initial water;

$\mathrm{U}=$ Humidity (\%);

$\mathrm{Ma}=$ Initial mass.

With this, the humidity that before was of $5.9 \%$ in the standard trait passed to $3,9 \%$.

In order to improve the cohesion between the cement and the aggregates, thus promoting a better finish, durability, resistance and reduction of the amount of water 
required, $0.83 \%$ superplasticizer additive was added to the mixture, in relation to the cement used, following the standard from factory production to structural blocks.

Sixteen blocks of dimensions of $14 \times 19 \times 39 \mathrm{~cm}$ were molded for each formulated trait, totaling 48 blocks. These were molded and pressed in a hydraulic vibro-press machine set up for 20 seconds cycles. Each cycle is made of four blocks, the maximum amount that the shape of the press allows.

The equipments that were used during the research were: vibro hydraulic press, debris grinder, greenhouse, sieves with ABNT classification and a mixer, as shown in Figure 5.

Figure 5 - Equipment: 1) Vibro hydraulic press; 2) Debris grinder; 3) Stove; 4) Sieves; 5) Mixer.

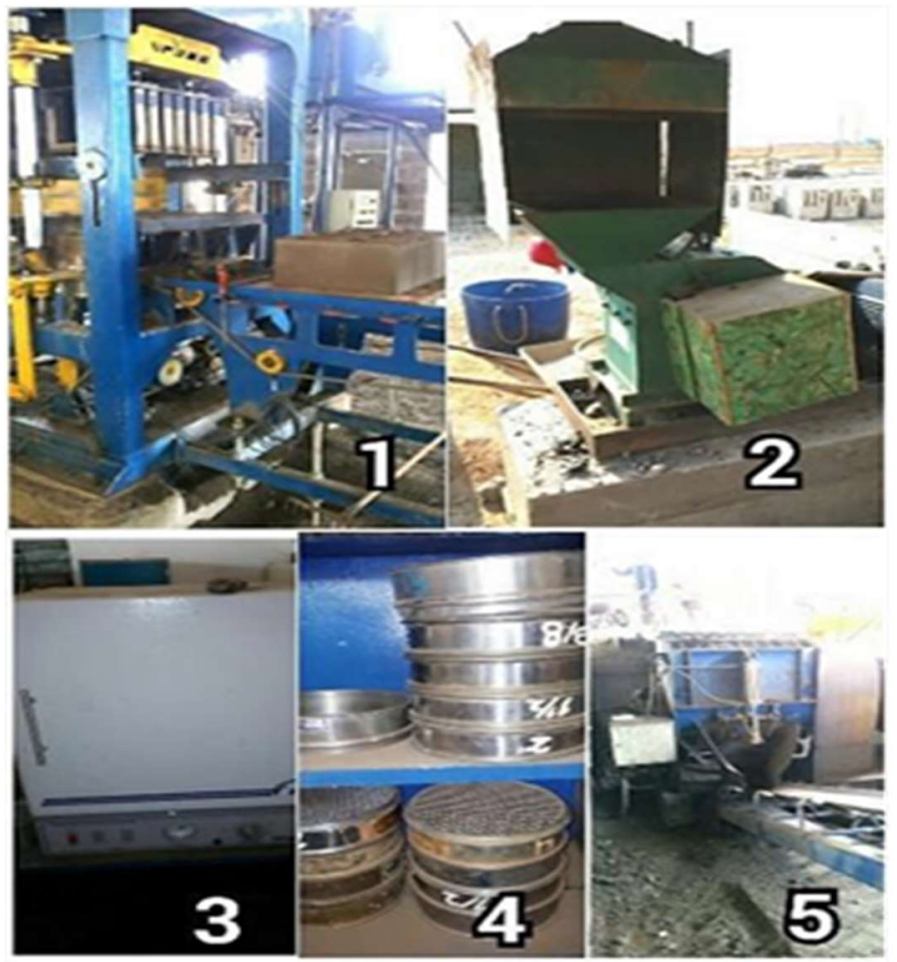

Source: own collection, 2014.

After molding, the 48 blocks entered the healing process, and for twenty-eight days they remained outdoors, protected from the weather and constantly moistened.

At the end of the twenty-eight days, 12 blocks of each trait were sent to the SENAI Laboratory in Cuiabá-MT, $500 \mathrm{~km}$ from Sinop-MT, to be submitted to the tests of compression resistance, water absorption and dimensional analysis. All the tests were 
performed by a technical responsible and following the specifications of NBR12118 (ABNT, 2014) Blocks cast from simple concrete to masonry - Test methods.

For the compressive strength test a press was used that fulfilled all the requirements established by NBR 12118 (ABNT, 2014). In order to carry out the test, the test specimens underwent a process of regularization of the working faces with mortars that withstand the stresses of the test. Subsequently the specimens were positioned in the press so that their center of gravity is in the load axis of the press plates and that the load is applied in the direction of the stress, which the block must resist during its use. The compressive strength was calculated by the maximum load supported by the specimen.

The water absorption test was performed using a balance with a minimum resolution of 10 grams and a greenhouse capable of maintaining the temperature in the range of $(110 \pm 5)^{\circ} \mathrm{C}$.

The specimens were weighed and then brought to the oven at $(110 \pm 5)^{\circ} \mathrm{C}$ for 24 hours, after the test, the specimens were weighed again, and then brought to the greenhouse for another 2 hours. This procedure shall be repeated every 2 hours until the variation of the mass of the test specimen from one weighing to another is less than $0,5 \%$. When it happens, dry mass is obtained.

To perform the saturation, the test bodies were immersed, after being cooled naturally, in water at $(23 \pm 5)^{\circ} \mathrm{C}$ for 24 hours. Subsequently the body is removed from the water, allowed to drain on a surface for 60 seconds, wiped with a cloth to remove excess water, and weighed. The test specimen was again immersed in water, withdrawn and weighed every 2 hours until the difference in mass between one weighing and another weighing is less than $0.5 \%$. When it happens saturated mass is obtained.

The difference between dry mass and saturated mass allowed us to calculate the percentage of water absorption of the test specimen.

To carry out the dimensional analysis, a calibrated metal scale was used, according to NBR 12118 (ABNT, 2014). The scale must have a resolution of at least $1 \mathrm{~mm}$ and adequate length of the maximum dimension of the specimen. 
During the test, at least 3 determinations were carried out at different points on each face. For verification of the minimum wall thickness, two determinations shall be made on each longitudinal wall of the block and one determination on each transverse wall.

The minimum thickness shall be the average of the measurements of the walls at the narrowest point, separated longitudinally and transversely.

For the verification of the holes dimensions of the blocks, two determinations must be made in the approximate center of each hole of the block, one in the longitudinal direction and another in the transverse direction.

The analysis of the radius of the corbels, according to the standard norm, must be made by tracing a transverse axis over the central septum, and determinations must be made in each shell, with center taken in the encounter of the outer face of the longitudinal wall with the transverse axis of the block, Always taken in the face of smaller thickness.

With the results of the tests, it was possible to compare compressive strength and water absorption between blocks using debris as a small aggregate and Class B blocks using conventional aggregates.

\section{Analysis and Results}

The test for determination of measurements and thicknesses presented satisfactory results. Making sure that the molded blocks follow the specifications of standard NBR 6136 (ABNT, 2006), in which they should not show cracks or imperfections in their measurements.

Figure 6 shows the results of the water absorption tests for the standard trace responses with residue trace results.

(Continue...)

Figure 6 - Percentage of water absorption in blocks. 


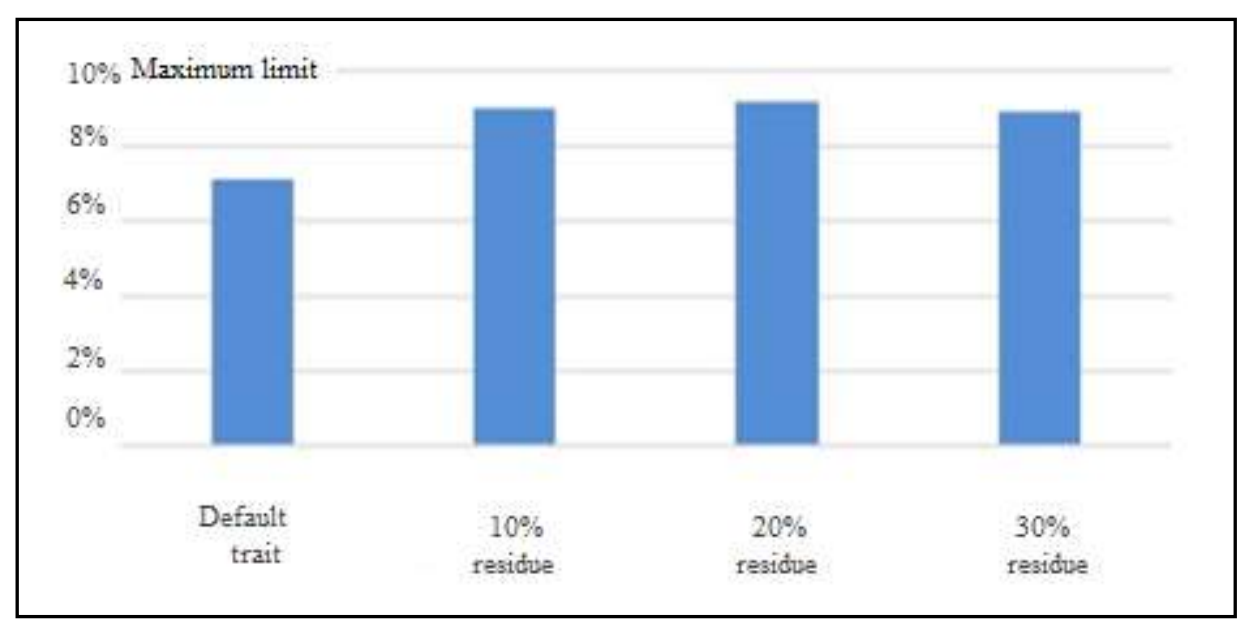

Source: own collection, 2014

In this way it is observed that, as residue is added, the water absorption increases approximately $26 \%$ in relation to the standard, for the first trace of $10 \%$ residue. It increases $29 \%$ for the second trace and $25 \%$ for the last trace of $30 \%$ residue.

In 2006, Souza found similar results using concrete residues, even though they did not use the same traces. It was verified that the debris used as aggregate presents superior absorption to the conventional aggregate. The author justifies this increase due to the great porosity, as well as the greater amount of fines that the residues have.

Figure 7 shows the results of the compressive strength tests.

Figure 7 - Test result of resistance to compression.

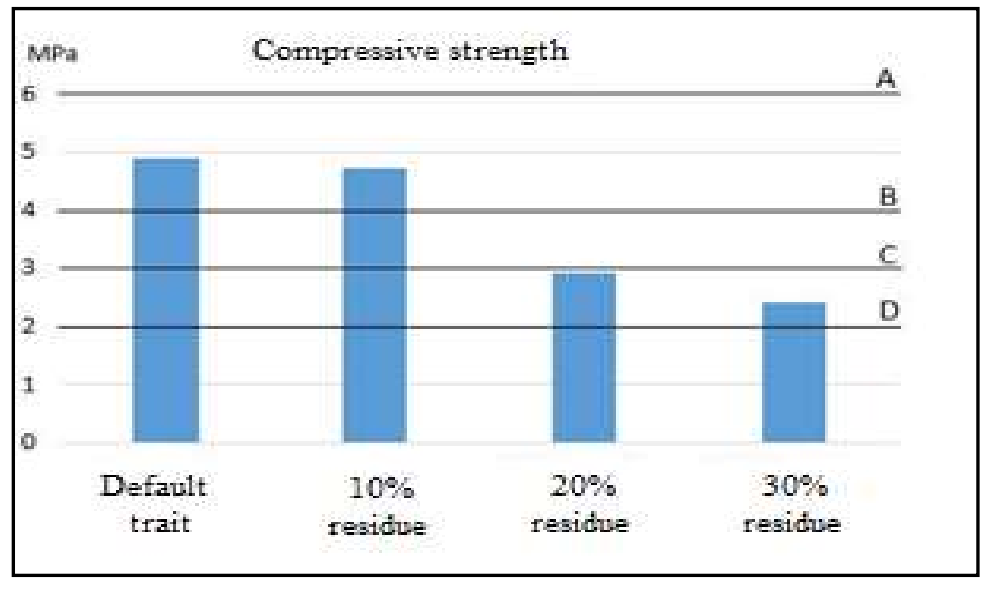

Source: own collection, 2014. 
Compared with the industry standard trait, blocks with $10 \%$ residue lost little compressive strength (less than 3.5\%). Decreasing from 4.90 Mpa to $4.73 \mathrm{MPa}$ at 28 days. However, it remains in class B.

The trace with $20 \%$ of waste loses $40 \%$ of its resistance to compression, reaching 2.93 $\mathrm{MPa}$. The last trait with the content of $30 \%$ of waste loses $51 \%$, reaching $2.4 \mathrm{MPa}$ of compressive strength.

With this, it is understandable the real use of waste. The use of the $10 \%$ residue substitution feature means consuming $300 \mathrm{~g}$ of waste per manufactured block.

An industry with production of 6 thousand blocks / day could use 1,800 kg / day of waste. According to studies of this industry, the waste generated is equivalent to $0.1 \%$ of the daily production, that is, $72 \mathrm{~kg}$. Therefore, this industry can eliminate waste generated by itself and continue with blocks of quality and class $B$.

\section{Conclusion}

The research demonstrated that, although there are no specific norms for the use of residues in concrete with structural function, their use in the production of class B cast concrete blocks is feasible with respect to the dimensional, water absorption and compressive strength.

However, it was verified that the use of concrete residues in blocks of structural concrete resulted in an increase in the water absorption rate, which it is corroborated by studies carried out by Souza (2006), which it demonstrates that, depending on the porosity of the residues, there may be an increase in water absorption.

It should be noted that in the substitution percentages adopted these values did not exceed the specifications required by NBR 6136 (ABNT, 2006), they do not prevent the use of the blocks produced.

The blocks produced with $10 \%$ of residues had a compressive strength of more than $4 \mathrm{MPa}$ and met the dimensional requirements and absorption of water and could therefore be used as blocks of class B. However, the blocks manufactured with $20 \%$ and $30 \%$ 
percentages, despite being within the dimensional limits and water absorption, did not reach the minimum resistance, and therefore do not fall into class $B$. Although they cannot be used in structural masonry, they can be applied as a sealing block, thus also contributing to a more appropriate disposal of waste.

It is noteworthy that with the result of this work it was verified that the industry where the research was carried out is able to consume the entire residue produced by it. The residue comes from the manufacture of blocks, thus reducing the use of natural resources and contributing to the minimization of environmental impacts due to the production and incorrect disposal of waste.

\section{References}

ASSOCIAÇÃO BRASILEIRA DE NORMAS TÉCNICAS (ABNT). NBR 12655. Concreto preparo, controle e recebimento. Rio de Janeiro. 1996. 3p.

ASSOCIAÇÃO BRASILEIRA DE NORMAS TÉCNICAS (ABNT). NBR 6136: Blocos vasados de concreto simples para alvenaria - Requisitos. Rio de Janeiro. 2006. $9 p$.

ASSOCIAÇÃO BRASILEIRA DE NORMAS TÉCNICAS (ABNT). NBR 12118: Blocos vazados de concreto simples para alvenaria - Métodos de ensaio. Rio de Janeiro. 2014.

BERENGUER, D. S. Técnica de execução de alvenaria estrutural. 2010. 17p. Universidade Católica do Salvador.

CAMACHO, J. S. Projeto de edifícios de alvenaria estrutural. 2006. 48p. Universidade Estadual Paulista"Júlio de Mesquita Filho". NEPAE (Núcleo de ensino e pesquisa da alvenaria estrutural), Ilha Solteira.

CÂNDIDO, E. da. Viabilidade técnica da implantação de uma usina de reciclagem de resíduos da construção civil em Sinop-MT. 2012. Trabalho de Conclusão de Curso Engenharia Civil. Universidade do Estado de Mato Grosso. Sinop, 2012.

\section{DALPINO, C. E. R. Utilização de resíduos da construção civil para a produção de} concreto. 2008. 57p. Monografia (Trabalho de Conclusão do Curso de Graduação em Engenharia Civil). Universidade Anhembi Morumbi, São Paulo.

MEDEIROS, J. S. A alvenaria estrutural não armada de bloco de concreto: Produção de Componentes e Parâmetros de Projeto. 1993. 8p. Dissertação (Mestrado em Engenharia de Construção Civil). Escola Politécnica/USP. São Paulo. São Paulo. 
MEHTA, P. K.; MONTEIRO P,. J. M. Concrete - Microstructure, properties and materials. 3rd ed. 2006 University of California at Berkeley. 659p.

MORAES, M. Dosagem de concreto. Goiás: Pontifícia Universidade Católica de Goiás, 2012. 13 slides: Slides gerados a partir do software PowerPoint.

OLIVEIRA, M. J. E.; ASSIS, C. S.; MATTOS, J. T. Recycled Aggregate Standardization In Brazil. 2004. 10p. Universidade Estadual Paulista, UNESP.

OLIVEIRA, I.; ARAÚJO J. Apostila Maco I - Agregados e Aglomerantes. Apostila para a disciplina de Materiais de Construção I. 2013. 27p. Pontifícia Universidade Católica de Goiás, Goiânia.

PIRES SOBRINHO, C. W. A; ARAÚJO, G.P.; MARQUES, L. LIMA, M.T.A de; SOUZA, R.V.R DE; Bloco de concreto: característica do processo de produção na região metropolitana do Recife. In: ENCONTRO NACIONAL DA ENGENHARIA DE PRODUÇÃO, n. XXVIII, 2008, Rio de Janeiro. Rio de Janeiro: ENEGEP.

SOUSA, J. G. G. Contribuição ao estudo da relação entre propriedades e proporcionamento de blocos de concreto - aplicação ao uso de entulho como agregado reciclado. 2001. 120p. Dissertação (Mestrado em Estruturas e Construção Civil). Universidade de Brasília, Brasília.

SOUZA, C. A. Utilização de resíduo de concreto como agregado miúdo para argamassa de concreto estruturais convencionais. 2006. 101p. Dissertação (Pós Graduação em Construção Civil). Universidade Federal de Minas Gerais, Belo Horizonte.

ZORDAN, S. E.; PAULON, V. A. A utilização do entulho como agregado para o concreto. 10p. In: ENCONTRO NACIONAL DE TECNOLOGIA DO AMBIENTE CONSTRUÍDO, n VII, 1998, Florianópolis. ARTIGO TÉCNICO; 1998, Florianópolis, Santa Catarina. 